\title{
Rekonstruksi Nilai-Nilai Pancasila dalam Undang-Undang
}

\author{
Madaskolay Viktoris Dahoklory ${ }^{1 *}$, Lita Tyesta Addy Listya Wardhani ${ }^{2}$ \\ ${ }^{1,2}$ Fakultas Hukum Universitas Diponegoro, Semarang, Indonesia \\ *E-mail: viktorisdahoklory@gmail.com
}

\begin{tabular}{|c|c|}
\hline Dikirim: 02/03/202C & Dipublikasi: 03/09/2020 \\
\hline Info Artikel & Abstract \\
\hline $\begin{array}{l}\text { Keywords: } \\
\text { Reconstruction; } \\
\text { Pancasila Values; } \\
\text { Law. }\end{array}$ & $\begin{array}{l}\text { Pancasila is the source of all sources of State law, by placing Pancasila } \\
\text { as a source of state law, Pancasila has a function as a guiding star in } \\
\text { the formation of national legal products. The purpose of the Writing is } \\
\text { to analyze and understand the transformation of the values of Pancasila } \\
\text { in the context of the renewal of national legal products and the } \\
\text { mechanism of testing and harmonization of laws with the values of } \\
\text { Pancasila. The research method used is juridical-normative and } \\
\text { qualitative analysis. The results of the study show that several national } \\
\text { legal products do not reflect Pancasila values, such as the water } \\
\text { resources law, this was proven when the Constitutional Court issued its } \\
\text { decision, which in essence the Constitutional Court stated that the law } \\
\text { contrary to the values of Pancasila as implemented in the constitution. } \\
\text { Therefore, the Government needs to increase its role in managing and } \\
\text { harmonizing regulations as an effort to renew national legal products } \\
\text { that are responsive in character. }\end{array}$ \\
\hline & Abstrak \\
\hline $\begin{array}{l}\text { Kata Kunci: } \\
\text { Rekonstruksi; Nilai- } \\
\text { nilai Pancasila; } \\
\text { Undang-Undang. }\end{array}$ & $\begin{array}{l}\text { Pancasila merupakan sumber dari segala sumber hukum Negara, dengan } \\
\text { di tempatkannya pancasila sebagai sumber hukum negara maka } \\
\text { pancasila memiliki fungsi sebagai bintang pemandu dalam } \\
\text { pembentukan produk hukum nasional. Tujuan Penulisan untuk } \\
\text { menganalisis dan memahami transformasi nilai-nilai pancasila dalam } \\
\text { rangka pembaharuan produk hukum nasional serta mekanisme } \\
\text { pengujian dan harmonisasi undang-undang dengan nilai-nilai pancasila. } \\
\text { Metode penelitian yang digunakan yaitu yuridis-normatif dan } \\
\text { menganalisis secara kuailatif. Hasil penelitian menunjukan bahwa } \\
\text { beberapa produk hukum nasional belum mencerminkan nilai-nilai } \\
\text { pancasila, seperti undang-undang sumber daya air hal ini terbukti ketika } \\
\text { Mahkamah Konstitusi mengeluarkan putusannya, yang pada pokoknya } \\
\text { Mahkamah Konstitusi menyatakan bahwa undang-undang tersebut } \\
\text { bertentangan dengan nilai-nilai pancasila sebagaimana telah } \\
\text { terimplementasi dalam konstitusi. Oleh karena itu Pemerintah perlu } \\
\text { meningkatkan perannya dalam menata dan mengharmonisasi regulasi } \\
\text { sebagai upaya memperbaharui produk hukum nasional yang berkarakter } \\
\text { responsif. }\end{array}$ \\
\hline
\end{tabular}




\section{A. PENDAHULUAN}

Bangsa Indonesia merupakan bangsa yang lahir karena keberagaman dan kemajemukan yang dipersatukan oleh niat tulus dan kesadaran masyarakat itu sendiri untuk hidup sebagai bangsa yang merdeka dan berdaulat. Melalui perjuangan yang panjang untuk bersatu, dilalui dengan begitu banyak tantangan, kepahitan, dan bahkan perjuangan fisik. Bukan hal yang mudah bagi para pendiri bangsa (the founding father's) untuk menyepakati Pancasila yang merupakan kristalisasi nilai-nilai luhur bangsa dan menetapkannya sebagai dasar negara. ${ }^{1}$ Sebagai falsafah negara, tentunya Pancasila merupakan karunia yang tiada tara dari Tuhan Yang Maha Esa kepada Bangsa Indonesia. Pancasila menjadi sumber cahaya bagi seluruh rakyat Indoensia dalam membangun peradabannya di masa-masa yang akan datang. $^{2}$

Berdasarkan data sejarah perjuangan bangsa Indonesia, semasa Revolusi kemerdekaan Bangsa Indonesia dalam kurun waktu 1945-1950, maka pada tanggal 1 Juni 1945, Ir. Soekarno, dengan panggilan akrabnya Bung Karno, atas permintaan dr. Rajiman Wedyodiningrat selaku Ketua Badan Usaha Penyelidik Usaha Persiapan Kemerdekaan (BPUPK) untuk mengucapkan pidatonya mengenai pemberian dasar-dasar dari Negara Indonesia yang akan didirikan. Pidato Bung Karno pada tanggal 1 Juni 1945, kemudian disebut hari lahirnya Pancasila, yang diucapkan dalam sidang Badan Usaha Penyelidik Usaha Persiapan Kemerdekaan (BPUPK). Dalam Pidato Bung Karno menyampaikan pendapatnya bahwa dasar negara terdiri dari: "Kebangsaan Indonesia, Internasionalisme atau Perikemanusiaan, Mufakat atau Demokrasi, Kesejahteraan Sosial, dan Bertakwa kepada Tuhan Yang Maha Esa. Dari lima dasar tersebut oleh Soekarno diberi nama Pancasila, kemudian diperas menjadi tiga sila, yaitu; Sosio-Nasionalisme, Sosio-Democratie, dan Ketuhanan. Selanjutnya diperas menjadi satu sila yaitu; Gotong Royong atau Eka Sila"”3

Kemudian, mendapat penyempurnaan pada tanggal 22 Juni Tahun 1945 oleh Panitia Kecil yang menghasilkan Mukadimah/Pembukaan Undang-Undang Dasar selanjutnya mendapat legitimasi pada tanggal 18 Agustus 1945 oleh PPKI dengan mengesahkan Pembukaan Undang-Undang Dasar Negara Republik Indonesia. Selama kurang lebih 20 Tahun sejak reformasi, tanpa disadari atau mungkin juga tanpa disengaja, wacana tentang sila-sila Pancasila makin tersisih dari perbincangan umum. Mungkin saja dikarena kebebasan yang diberikan sejak masa reformasi telah membuat setiap orang lupa diri. Kebebasan dinikmati sampai kepada titik maksimum yang mungkin dicapai. Padahal kebebasan tanpa keteraturan pastilah menciptakan kekacauan dalam kehidupan bermasyarakat.

Kebebasan hanya akan bermanfaat bagi kehidupan masyarakat apabila dibarengi dengan tegaknya keadilan sebagaimana terkandung dalam instrumen hukum dan konstitusi sebagai pegangan bersama dalam kehidupan bernegara. Hukum dalam kedudukannya yang paling tinggi, itulah yang dinamakan konstitusi namun yang menjadi roh dan jasadnya konstitusi, yaitu nilai-nilai Pancasila dan Tujuan Bernegara. dalam kehidupan bernegara Pancasila dan Tujuan Bernegara itu harus diterjemahkan dengan sungguh-sungguh dalam setiap kebijakan publik. Setiap kebijakan publik yang dituangkan dalam bentuk hukum

1 Amarini, I. (2017). Evaluasi Aktualisasi Pancasila Melalui Harmonisasi Hukum. Jurnal Kosmik Hukum. 17 (2), h. 80

2 Brata, Ida. B. \& Wartha, Ida B. N. (2017). Lahirnya Pancasila sebagai Pemersatu Bangsa Indonesia. Jurnal Santiaji Pendidikan. 7 (1), h. 121

3 Hardinanto, A. (2017). Autentitas Sumber Sejarah Pancasila Dalam Masa Persidangan Pertama Badan Untuk Menyelidiki Usaha-Usaha Persiapan Kemerdekaan Indonesia Tanggal 29 Mei - 1 Juni 1945. Jurnal Veritas et Justisia. 3 (1), h. 59 
tertentu, haruslah mencerminkan nilai-nilai Pancasila dan Tujuan Bernegara. Dengan begitu, setiap hukum dan konstitusi dapat dibaca dan dimaknai dengan benar atas dasar moral dan ideologi yang melandasinya. Pancasila tidak hanya berisi rasionalitas ide-ide, tetapi juga mengandung muatan prinsip-prinsip moral dan etika kebangsaan Indonesia. ${ }^{4}$

Namun apabila ditelusuri sejak kemerdekaan Bangsa Indonesia pada tanggal 17 Agustus Tahun 1945. Baik itu, masa Orde Lama kurun waktu Tahun 1945-1965, Orde Baru Tahun 1966 -1998, dan era reformasi pada Tahun 1999 hingga sekarang masih banyak produk-produk hukum dalam arti Undang-Undang yang belum mencerminkan roh, jiwa, maupun moral dari Bangsa Indonesia yaitu nilai-nilai Pancasila itu senidri. Antara lain Kitab Undang-Undang Hukum Pidana, Kitab Undang-Undang Hukum Perdata, Undang-Undang Pemilu, Undang-Undang Sumber Daya Air, dan lain sebagainya.

Undang-Undang yang disebutkan diatas hanyalah merupakan cerminkan kekuasaan dan kepentingan politik dari pihak-pihak yang berkuasa maupun Undang-Undang yang demikian hanyalah warisan peninggalan para penjajah yang filosofisnya masih mencerminkan nilai-nilai dan budaya asing. Seperti yang disebutkan sebelumnya bahwa salah satu produk hukum era reformasi yang tidak mencerminkan nilai-nilai Pancasila, bisa ditemukan dalam Undang-Undang Nomor 7 Tahun 2004 tentang Sumber Daya Air, oleh karena itu dalam penulisan ini hanya terbatas pada produk hukum nasional dalam arti Undang-Undang Sumber Daya Air. Dengan demikian, dalam Penulisan ini akan mengkaji : Bagaimana Transformasi nilai-nilai Pancasila dalam rangka Pembaharuan Produk Hukum Nasional serta Bagaimana mekanisme pengujian dan harmonisasi Undang-undang yang bertentangan dengan Pancasila?

\section{B. METODE PENELITIAN}

Penelitian ini bersifat normatif, dengan menggunakan pendekatan perundangundangan (statute approach) dilakukan dengan cara menelaah semua undang-undang dan regulasi yang berkaitan dengan isu hukum. Serta pendekatan konseptual (conceptual approach) beranjak dari doktrin-doktrin, asas-asas hukum serta pengertian hukum yang diperlukan untuk menjelaskan permasalahan yang hendak dikaji.

\section{PEMBAHASAN}

\section{Tranformasi Nilai-nilai Pancasila dalam rangka Pembaharuan Produk Hukum Nasional}

\section{a. Mewujudkan Politik Hukum yang Ideal}

Setiap Negara pasti mempunyai politik hukumnya sendiri-sendiri baik negara maju maupun negara berkembang. Begitu juga dengan Indonesia tentunya mempunyai politik hukum tersendiri. Politik Hukum itu pastinya berisi arah pembaharuan hukum nasional demi mewujudkan cita-cita dan tujuan negara Indonesia. ${ }^{5}$ Sri Soemantri pernah mengemukakan pendapatnya tentang hubungan politik dan hukum yang diibaratkan perjalanan lokomotif kereta api yang keluar dari relnya. Jika hukum ibarat rel dan politik diibaratkan lokomotif maka sering terlihat lokomotif itu keluar dari rel yang seharusnya dilalui. Politik dan hukum

2

4 Asshiddiqie, J. (2015). Penguatan Sistem Pemerintahan dan Peradilan. Jakarta: Sinar Grafika, h. 1-

5 Rahayu, D. P. (2015). Aktualiasasi Pancasila Sebagai Landasan Politik Hukum Indonesia. Yustisia, 4 (1), h. 191

299 |S A S I Vol. 26 No.3, Juli-September 2020 
adalah dua hal yang tidak bisa dipisahkan melainkan harus bekerja sama dan saling menguatkan, seperti ungkapan "hukum tanpa kekuasaan adalah angan-angan dan kekuasaan tanpa hukum adalah kelaliman". Namun realitasnya dalam tataran implementasi hukum kerapkali menjadi cermin dari kehendak pemegang kekuasaan politik sehingga tidak sedikit orang memandang bahwa hukum sama dengan kekuasaan. Apeldoorn, misalnya mencatat, ada beberapa pengikut paham bahwa hukum adalah kekuasaan. Pertama kaum Sofis di yunani yang mengatakan keadilan adalah apa yang berfaedah bagi orang lebih kuat. Kedua, Gumplowics mengatakan hukum berdasar atas penaklukan yang lemah oleh yang kuat, hukum adalah susunan definisi yang dibentuk oleh pihak yang kuat untuk mempertahankan kekuasaannya.

Sehubungan dengan lebih kuatnya energi politik apabila berhadapan dengan hukum maka acapkali hukum diintervensi oleh politik. Itu sebabnya, tidak heran apabila orang sering menyebut hukum sebagai produk politik, maka politik akan sangat menentukan karakter produk hukum seperti apa yang dihasilkan. Dalam kaitannya dengan politik hukum Mahfud MD, dalam bukunya "Politik Hukum di Indonesia" sering menggunakan istilah konfigurasi politik yang demokratis dan konfigurasi politik yang otoriter, serta produk hukum yang berkarakter responsif dan konservatif. Jika konfigurasi politik yang demokratis maka nantinya melahirkan produk hukum yang berkarakter responsif, sebaliknya apabila konfigurasi politik yang otoriter maka akan melahirkan produk hukum yang berkarakter konservatif. Produk hukum yang dimaksudkan dalam hal ini adalah Undang-undang. Contoh UUPA (Undang-Undang Pokok Agraria) adalah produk hukum yang berkarakter responsif karena dapat menjawab masalah pertanahan hingga masa reformasi. Sebaliknya UU Pemilu adalah produk hukum yang berkarakter konservatif karena dibentuk berdasarkan kepentingan elite politik sehingga selalu dilakukan perubahan. ${ }^{6}$

Konfigurasi Politik yang Demokratis dapat tercermin dalam setiap produk hukum nasional apabila pembentuk hukum menggunakan pendekatan Politik Hukum yang Ideal. Dalam hal ini yang dimaksud dengan Politik Hukum Ideal adalah kebijakan pembentukan hukum dalam arti undang-undang yang harus mengacu dan sesuai dengan cita hukum (recthsidee) serta Tujuan Negara. Negara Indonesia memiliki (rechtsidee) cita hukum yang ingin dicapai oleh Bansa Indonesia yaitu Pancasila ${ }^{7}$ dan Tujuan Negara yang tercantum dalam Pembukaan UUD NRI 1945 Alinea Ke-empat antara lain: Melindungi segenap Bangsa Indonesia dan Seluruh tumpah darah Indonesia; memajukan kesejahteraan umum; mencerdaskan kehidupan bangsa; dan ikut serta melaksanakan ketertiban dunia berdasarkan kemerdekaan, perdamaian abadi, dan keadilan sosial.

Pancasila dan Tujuan Negara sebagaimana tercantum dalam Pembukaan UUD 1945 Alinea ke-empat inilah yang dinamakan Politik Hukum Ideal. Oleh karena itu, setiap kebijakan nasional dalam rangka pembaharuan hukum seharusnya mengacu serta dapat menerjemahkan nilai-nilai Pancasila dan Tujuan Bernegara dalam setiap produk hukum nasional baik itu Undang-undang maupun peraturan perundang-undangan lainnya.

\section{b. Transformasi Nilai-Nilai Pancasila dalam materi muatan Undang-undang}

Transformasi dalam hal ini merupakan suatu metode atau cara untuk menyalin atau memindahkan nilai-nilai Pancasila ke dalam produk hukum nasional baik itu undang-undang maupun perundang-undangan lainnya. Mentransformasi nilai-nilai pancasila itu sendiri

6 MD, Mahfud. (2012). Politik Hukum di Indonesia, Depok: Rajawali PERS, h. 20-22

7 Tardjono, H. (2016). Reorientasi Politik Hukum Pembentukan Undang-Undang di Indonesia. Jurnal Renaissance, 1 (2). h. 61 
dapat dilakukan melalui proses pembentukan peraturan perundang-undangan sebagai upaya untuk memperbaharui hukum nasional. Menurut "A. Hamid S. attamimi" yang mengutip Juridish woordenboek, kata perundang-undangan (wetgeving) mengandung dua macam arti, yaitu; Pertama, proses pembentukan peraturan-peraturan negara dari jenis yang tertinggi yaitu undang-undang (wet) sampai yang terendah yang dihasilkan secara atribusi atau delegasi dari kekuasaan perundang-undangan; Kedua, keseluruhan produk peraturanperaturan negara tersebut. ${ }^{8}$ Pembentukan peraturan perundang-undangan merupakan metode atau cara untuk membangun hukum nasional, di samping penerapan hukum, dan penegakan hukum. Pembangunan hukum hanya akan terlaksana secara komprehensif apabila meliputi substansi hukum, kelembagaan hukum, dan budaya hukum serta dibarengi dengan penegakkan hukum secara konsisten dengan tetap menjunjung tinggi hak asasi manusia, dengan begitu fungsi hukum sebagai sarana pembaruan dan pembangunan nasional yang diharapkan dapat berjalan sesuai cita hukum dan Tujuan Negara. ${ }^{9}$

Jika berpedoman pada teknik Pembentukan peraturan perundang-undangan di Indonesia maka sekurang-kurangnya harus memuat tiga landasan utama, yaitu; Filosofis, Yuridis, dan Sosiologis. Item yang semestinya dimuat dalam landasan filosofis adalah cita hukum (rechtside) yaitu nilai-nilai pancasila dan Tujuan Negara (Pembukaan UUD 1945). Pancasila dalam kehidupan bermasyarakat berfungsi sebagai Pandangan Hidup (way of life), Pancasila dalam kehidupan berbangsa berfungsi sebagai Ideologi Bangsa (Alat pemersatu bangsa), dan Pancasila dalam kehidupan Bernegara berfungsi sebagai Dasar Negara (staatsfundamentalnorm). Pancasila sebagai norma fundamental negara dan sebagai cita hukum merupakan sumber, dasar, dan pedoman bagi pembentukan peraturan perundangundangan yang berada dibawahnya sehingga pancasila dalam tatanan hukum di Indonesia memiliki dua dimensi, yaitu "(1) sebagai norma kritik, yakni menjadi batu uji bagi normanorma di bawahnya, dan (2) sebagai bintang pemandu yang menjadi pedoman dalam pembentukan hukum di bawahnya". Atau dengan kata lain, menurut Muladi, bahwa Pancasila merupakan instrument dari "Margin of Appreciation Doctrine". 10 Penempatan Pancasila sebagai staatsfundamentalnorm pertama kali disampaikan oleh Notonagoro. Pancasila dilihat sebagai cita hukum (rechtsidee) merupakan bintang pemandu. Posisi ini mengharuskan pembentuk hukum positif untuk dapat mencapai ide-ide yang terkandung dalam Pancasila, serta dapat digunakan untuk menguji hukum positif.

Dengan ditempatkan Pancasila sebagai staatsfundamentalnorm maka pembentukan hukum, penerapan hukum, dan pelaksanaannya tidak dapat dilepaskan dari nilai-nilai Pancasila. Namun, dengan menempatan Pancasila sebagai staatsfundamentalnorm berarti menempatkannya diatas Undan-Undang Dasar 1945. Jika demikian, Pancasila tidak termasuk dalam pengertian konstitusi karena berada diatas konstitusi. Maka dalam hal ini, Teori Stunffenbau des Rechts "Hans Kelsen" dapat dijadikan barometer. Menurut "Kelsen", bahwa sistem hukum merupakan anak tangga dengan kaedah hukum berjenjang dimana norma yang lebih rendah harus berpegangan kepada norma yang lebih tinggi dan norma yang lebih tinggi harus berpegangan kepada norma dasarnya. ${ }^{11}$ Pancasila sebagai norma dasar negara dalam kerangka hukum positif Indonesia ditempatkan sebagai sumber dari segala sumber hukum Negara, Hal ini ditegaskan dalam Pasal 2 UU No 12 Tahun 2011 sebagaimana

8 Aditya, Z. F. \& Winata, M. R. (2018). Rekonstruksi Hierarki Peraturan Perundang-Undangan di Indonesia. Jurnal Negara Hukum, 9 (1), h. 88-89

9 Astomo, P. (2018). Ilmu Perundang-Undangan (Teori dan Praktik di Indonesia). Depok: Rajawali Pers, h. 71

10 Muladi. (2005). Menggali Kembali Pancasila sebagai Dasar Pembangunan Ilmu Hukum. Jurnal Hukum Progresif, 1 (1), h. 35

${ }^{11}$ Suwandi. (2018). Program Pembentukan Peraturan Daerah Perkemabangan dan Permasalahannya. Jurnal Legislasi Indonesia. 15 (3), h. 150

301 |S ASI Vo1.26 No.3, Juli - September 2020 
telah diubah dengan UU No 15 Tahun 2019 tentang Pembentukan Peraturan Perundangundangan. Apabila pembentuk Undang-Undang telah bersepakat untuk menjadikan Pancasila sebagai sumber segala sumber hukum negara, maka setiap kebijakan hukum yang dikeluarkan oleh penguasa dalam bentuknya yang formal yaitu undang-undang maupun Peraturan perundang-undangan lainnya, sejatinya harus tetap mencerminkan nilai-nilai Pancasila dan Tujuan Bernegara. Lebih lanjut mengenai substansi materi muatan yang harus dimuat dalam suatu Undang-Undang berisi antara lain : “(1) Pengaturan lebih lanjut mengenai ketentuan Undang-Undang Dasar Negara Republik Indonesia Tahun 1945; (2) Perintah suatu Undang-Undang untuk diatur dengan Undang-Undang; (3) Pengesahan Perjanjian Internasional tertentu; (4) Tindak lanjut Putusan Mahkamah Konstitusi; (5) Pemenuhan kebutuhan hukum dalam masyarakat". ${ }^{12}$

Selain, materi muatan undang-undang sebagaimana diuraikan diatas. Penulis sependapat dengan "Backy Krisnayuda" yang menjelaskan bahwa Undang-Undang harus mencerminkan asas, kaidah, moral, serta akar bangsa itu sendiri, antara lain : "(1) Setiap Undang-undang harus membentuk dan mencerminkan pribadi bangsa yang bertakwa kepada Tuhan Yang Maha Esa; (2) Setiap Undang-undang harus mencerminkan nilai kemanusiaan dan menjunjung tinggi harkat dan martabat manusia; (3) Setiap Undang-undang harus menciptakan rasa aman dan damai dengan semangat persaturan dan kesatuan bangsa; (4) Setiap Undang-undang harus memberikan ruang keterwakilan anggota masyarakat dalam pembentukan, penerapan, dan pengujian undang-undang; (5) Setiap Undang-undang harus dapat menyejahterakan masyarakat" 13

Menurut hemat penulis substansi muatan Undang-Undang dituntut untuk dapat memberikan perlindungan terhadap masyarakat Indonesia, menjamin pelayanan umum, memberikan jaminan pendidikan untuk mencerdaskan kehidupan masyarakat, serta materi muatan yang berisi keadilan sosial atau keadilan yang sebenarnya diingini masyakarat. Dengan begitu, Indonesia akan mencapai titik puncak yang selama ini, didoakan oleh founding fathers yaitu negara kesejahteraan (welfare state)

\section{Pengujian dan Harmonisasi Undang-undang yang Bertentangan dengan Nilai-nilai Pancasila}

\section{a. Pengujian Undang-Undang Nomor 7 Tahun 2004 tentang Sumber Daya Air}

Sejarah panjang mengenai pengujian Undang-undang terhadap Undang-Undang Dasar yang ide dasarnya di lahirkan oleh John Marshall dari Amerika (1803) yang kemudian melahirkan istilah Judicial Review. Dengan adanya judicial review, undang-undang yang berasal dari proses politik dapat dinilai atau diuji konstitusionalitasnya terhadap UndangUndang Dasar yang merupakan peraturan tertinggi dalam suatu Negara. Sementara itu, lembaga yang berwenang untuk menilai dan menguji undang-undang tersebut diletakkan kepada lembaga peradilan. Di Indonesia lembaga peradilan yang dimaksud adalah Mahkamah Konstitusi. ${ }^{14}$ Keberadaan Mahkamah Konstitusi sebagai pelaksana kekuasaan kehakiman yang menjaga dan mengawal kemurniaan konstitusi (the guardian of constitution) sebagai pengawal konstituai Mahkamah Konstitusi memiliki tugas dan wewenang sebagaimana diatur dalam Pasal 24C Undang-Undang Dasar Negara Republik Indonesia Tahun 1945. diantaranya Mahkamah Konstitusi berwenang untuk menguji Undang-Undang

12 Undang-Undang Nomor 12 Tahun 2011 Juncto Undang-Undang Nomor 15 Tahun 2019

13 Krisnayuda, B. (2017). Pancasila \& Undang-Undang, Relasi dan Transformasi Keduanya Dalam Sistem Ketatanegaraan Indonesia. Jakarta: Kencana, h. 198

14 Pusat Studi Konstitusi FH Andalas. (2010). Perkembangan Pengujian Perundang-Undangan di Mahkamah Konstitusi. Jurnal Konstitusi. 7 (6), h. 148 
terhadap Undang-Undang Dasar ${ }^{15}$. Pengujian Undang-Undang merupakan salah satu mekanisme check and balances yang dilaksanakan oleh Mahkamah Konstitusi dalam mengawal tegaknya negara hukum. Sebagai lembaga negara yang berwenang menilai dan menguji konstitusionalitas suatu Undang-Undang terhadap UUD 1945, Putusan Mahkamah Konstitusi bersifat final and binding artinya sejak Putusan Mahkamah Konstitusi diucapkan dalam persidangan yang terbuka untuk umum, maka secara otomatis berlaku untuk semua orang (erga omnes), dan tidak adalagi upaya hukum yang dapat ditempuh untuk membatalkan Putusan tersebut. ${ }^{16}$

Pengujian Undang-Undang dalam perspektif waktu dapat dibedakan menjadi pengujian Undang-Undang sebelum Undang-Undang tersebut mendapatkan bentuk formal dan belum diundangkan sebagaimana mestinya. Pengujian ini disebut sebagai pengujian $a$ priori atau judicial preview. Pengujian a priori ini dilakukan untuk menghindari terjadinya kekeliliruan atau ketidaksinkronan dan tidak konsistensinya antar peraturan perundangundangan secara hierarkis atau bahkan bertentangan dengan nilai-nilai yang hidup dalam masyarakat. Pelaksanaan pengujian a priori ini tidak dilakukan oleh lembaga Pembentuk Undang-Undang, tetapi oleh lembaga lain yang kewenangannya diberikan oleh peraturan perundang-undangan. Sebagai contoh, di Perancis, Undang-Undang yang dibentuk dan disahkan oleh parlemen sebelum diundangkan, dilakukan pengujian a priori oleh Dewan Konstitusi (Constitutional Council) di Indonesia Lembaga semacam ini dikenal dengan sebutan Mahkamah Konstitusi. Sementara itu, pengujian peraturan perundang-undangan yang telah memperoleh bentuk formalnya dan sudah diundangkan, sebagaimana mestinya oleh lembaga yang berwenang dan disebut sebagai pengujian a posteriori atau judicial review. ${ }^{17}$

Selanjutnya mengenai tata cara pengujian Undang-Undang terhadap UUD 1945 telah di atur oleh Mahkamah Konstitusi dalam Peraturan Mahkamah Konstitusi Nomor 6 Tahun 2005 tentang "Pedoman Beracara dalam Pengujian Undang-Undang”. Sejak keberadaan Mahkamah Konstitusi di Indonesia pada Tahun 2003, banyak pihak-pihak baik dari kalangan akademisi, praktisi hukum, maupun LSM yang berlomba-lomba untuk memperjuangkan hak-hak konstitusional serta kepentingan-kepentingannya masing-masing melalui mekanisme pengujian undang-undang terhadap UUD 1945 di Mahkamah Konstitusi. Namun, apabila dicermati seringkali pokok permohonan para Pemohon hanya meminta Mahkamah untuk menilai dan melakukan pengujian Undang-Undang terhadap Pasal-Pasal (Batang Tubuh) UUD 1945. Akan tetapi, perlu diingatkan kembali bahwa sesungguhnya UUD NRI 1945 tidak hanya terdiri atas Pasal-Pasal (batang tubuh) melainkan terdiri atas Pembukaan dan Pasal-Pasal yang merupakan satu kesatuan yang tidak terpisahkan. Apabila dibaca dalam Pasal 24C Ayat (1) UUD 1945, telah menegaskan bahwa Mahkamah Konstitusi berwenang menguji Undang-Undang terhadap Undang-Undang Dasar Negara Republik Indonesia Tahun 1945. Pasal II Aturan Tambahan UUD 1945 mengingatkan kembali bahwa UUD NRI 1945 terdiri atas Pembukaan dan Pasal-Pasal.

Pembukaan UUD 1945 Alinea ke-empat berbunyi demikian, Kemudian dari pada itu untuk membentuk suatu Pemerintah Negara Indonesia yang "Melindungi segenap bangsa Indonesia dan seluruh tumpah darah Indonesia; dan untuk memajukan kesejahteraan umum; mencerdaskan kehidupan bangsa; dan ikut serta melaksanakan ketertiban dunia berdasarkan kemerdekaan, perdamaian abadi, dan keadilan sosial, maka disusunlah Kemerdekaan

15 Putera, A. (2018). Dualisme Pengujian Undang-Undang. Legislasi Indonesia. 15 (2), h. 72

16 Maulidi, M. A. (2017). Problematika Hukum Implementasi Putusan Final dan Mengikat Mahkamah Konstitusi Perspektif Negara Hukum. Ius Quia Iustum. 24 (4), h. 540

17 Hamidi, J. dkk. (2012). Teori Hukum Tata Negara A Turning Point of The state. Jakarta: Salemba Humanika, h. 149-150 
Kebangsaan Indonesia itu dalam suatu Undang-Undang Dasar Negara Indonesia, yang terbentuk dalam susunan Negara Republik Indonesia yang berkedaulatan rakyat dengan berdasar kepada Ketuhanan Yang Maha Esa, Kemanusiaan yang adil dan beradab, Persatuan Indonesia dan Kerakyatan yang dipimpin oleh hikmat kebijksanaan dalam Permusyawaratan/Perwakilan, serta dengan mewujudkan suatu Keadilan sosial bagi seluruh rakyat Indonesia". ${ }^{18}$

Pembukaan UUD NRI 1945 tepatnya Alinea ke-empat inilah yang merupakan batu uji yang ideal bagi Mahkamah Konstitusi untuk menilai suatu undang-undang bertentangan atau tidak dengan UUD NRI 1945 karena di situlah terkandung nilai-nilai Pancasila (rechtsidee) dan tujuan bernegara. Menariknya, Pada tanggal 18 Februari 2015, Mahkamah Konstitusi dalam Putusannya Nomor 85/PUU-XI/2013 mengenai perkara pengujian UU No 7 Tahun 2004 tentang Sumber Daya Air. Secara tidak langsung Mahkamah Konstitusi telah mengingatkan kembali fungsinya sebagai The Guardian of Ideology (Pengawal Ideologi Bangsa). Itu sebabnya, bila dicermati dalam pertimbangan hukumnya Mahkamah menyatakan bahwa UU a quo tidak sesuai dengan roh atau jantung bangsa Indonesia yaitu nilai-nilai Pancasila karena menurut Mahkamah Konstitusi air merupakan kebutuhan pokok masyarakat Indonesia yang harus dipenuhi oleh Pemerintah dan tidak boleh terhambat oleh mekanisme administrasi.

Pemerintah juga berkewajiban untuk mengelola dan memanfaatkan air untuk sebesarbesarnya kemakmuran rakyat bukan sebaliknya dimanfaatkan oleh Pemerintah untuk kepentingan komersial atau bisnis. Lebih jelasnya menurut "Mahkamah, Pasal 33 UUD 1945 merupakan bentuk konstitusionalitas dianutnya demokrasi ekonomi, selain demokrasi politik, yang terkait dengan penyelenggaraan negara sebagaimana dimaksud sila keempat dan sila kelima Pancasila. Terkait dengan implementasi ke dalam konstitusi Pasal 33 Ayat (3) UUD 1945 tidak hanya menunjukan sebagai dasar negara, melainkan juga sebagai tujuan negara. Dengan perkataan lain, sila kelima "keadilan sosial bagi seluruh rakyat Indonesia" sebagai dasar negara diimplementasikan dalam UUD 1945 mengenai penyelenggaraan negara di bidang ekonomi adalah bentuk demokrasi ekonomi dengan tujuan mewujudkan sebesar-besarnya kemakmuran rakyat. Itulah sesungguhnya makna inti keadilan sosial, yang juga diartikan sebagai masyarakat yang adil dan makmur". ${ }^{19}$ Itu sebabnya, Mahkamah Konstitusi secara tegas membatalkan UU SDA a quo sebagaimana terlihat dalam Amar Putusannya Nomor 3 \& 4 yang menyatakan bahwa "Undang-Undang Nomor 7 Tahun 2004 tentang Sumber Daya Air (Lembaran Negara Republik Indonesia Tahun 2004 Nomor 32, Tambahan Lembaran Negara Republik Indonesia Nomor 4377) bertentangan dengan Undang-Undang Dasar Negara Republik Indonesia Tahun 1945 dan tidak mempunyai kekuatan hukum mengikat"

\section{b. Akibat Hukum Putusan Mahkamah Konstitusi Nomor 85/PUU-XI/2013}

Sebagai lembaga peradilan yang diberi tanggungjawab untuk menegakan konstitusi. Mahkamah Konstitusi mempunyai beberapa karakter khusus yang berbeda dengan peradilan umum atau biasa. Kekhususan tersebut antara lain terletak pada putusannya yang bersifat final dan mengikat artinya bahwa ketika Putusan MK dibacakan dalam persidangan yang terbuka untuk umum maka sejak saat itu juga langsung dimuat dalam berita negara maka akibat hukumnya adalah tidak ada lagi upaya hukum lainnya yang dapat ditemput untuk membatalkan putusan tersebut. Akibat hukum Putusan MK melahirkan hak dan kewajiban

18 Arfa'i. (2015). Pembukaan UUD 1945 Sebagai Norma Hukum Dalam Etika Politik Guna Mencapai Tujuan Negara. Jurnal Ilmu Hukum. 6 (2), h. 91-92

19 Lihat "Putusan Mahkamah Konstitusi Nomor 85/PUU-XI/2013" h. 134 
hukum bagi para pihak, Pemerintah, DPR maupun semua warga negara (erga omnes). ${ }^{20}$ Seperti, halnya dalam Putusan Mahkamah Konstitusi Nomor 85/PUU-XI/2013 yang dibacakan pada sidang pleno Mahkamah Konstitusi yang terbuka untuk umum, Pada tanggal 18 Februari 2015 yang dalam pertimbangan hukumnya menyatakan antara lain: (a). "Undang-Undang SDA dinyatakan bertentangan dengan UUD 1945 dan untuk mencegah terjadinya kekosongan hukum pengaturan mengenai sumber daya air maka sembari menunggu pembentukan Undang-Undang baru yang memperhatikan putusan Mahkamah oleh pembentuk Undang-Undang, maka Undang-Undang Nomor 11 Tahun 1974 tentang pengairan diberlakukan kembali; (b). Meskipun Pemerintah telah menetapkan enam Peraturan Pemerintah untuk melaksanakan UU SDA a quo, namun menurut Mahkamah keenam Peraturan Pemerintah tersebut tidak memenuhi enam prinsip dasar pembatasan pengelolaan sumber daya air". Apabila dicermati kedua pertimbangan hukum Mahkamah diatas, menurut pandangan penulis, ada beberapa akibat hukum yang ditimbul setelah adanya Putusan a quo. Antara lain;

1. Ke-enam Peraturan Pemerintah sebagai peraturan pelaksanaan UU SDA menjadi batal secara otomatis;

2. UU No 11 Tahun 1974 tentang Pengairan menjadi berlakukan kembali;

3. Posisi Mahkamah Konstitusi dalam kasus diatas tidak bertindak sebagai Negative Legislature (membatalkan Undang-Undang) melainkan MK memposisikan dirinya sebagai Positive Legislature (Membentuk/menghidupkan kembali Undang-Undang).

Oleh karena itu, akibat hukum putusan MK yang demikian, sekiranya juga dapat diajukan beberapa pertanyaan kritis. Pertama, apakah UU Pengairan yang dinyatakan berlaku kembali oleh Mahkamah masih relevan dengan dinamika kehidupan masyarakat Indonesia hari ini. Kedua, jika UU pengairan masih relevan dengan dinamika kehidupan masyarakat Indonesia hari ini, dengan apakah Pemerintah menjadikan pedoman untuk menjalankan/melaksanakan UU a quo karena toh Peraturan Pelaksanaan hanya dimaksudkan bagi UU Nomor 7 Tahun 2004 yang notabene telah dibatalkan oleh Mahkamah Konstitusi. Ketiga, dalam pertimbangan Putusan MK menyatakan bahwa ke-enam Peraturan Pelaksana menjadi kehilangan relevansi alias menjadi batal secara otomatis, maka pertanyaannya adalah apakah MK berwenang untuk menyatakan begitu, karena secara konstitusional untuk membatalkan peraturan perundang-undangan dibawah UU merupakan ranah kewenangannya Mahkamah Agung ( vide Pasal 24A UUD NRI 1945 ), dan sesungguhnya masih banyak lagi pertanyaan-pertanyaan yang dapat diajukan sebagai respon akibat adanya Putusan Mahkamah tersebut. Namun, yang menarik adalah pasca adanya Putusan Mahkamah a quo, tiga Tahun berlalu lahirlah Undang-Undang Sumber Daya Air (SDA) terbaru yakni, Undang-Undang Nomor 17 Tahun 2019 tentang Sumber Daya Air. Maka, Pertanyaan pertama kali yang akan dilontarkan adalah apakah Pembentukan UU SDA terbaru yang dibentuk melalui proses politik oleh DPR dan Pemerintah telah mempertimbangkan Putusan Mahkamah Konstitusi yang antara lain, telah memberikan "enam prinsip pembatasan penguasaan air" sebagai upaya untuk menjaga kelestarian dan keberlanjutan ketersediaan air bagi kehidupan bangsa, sebagai berikut : ${ }^{21}$

1) Setiap pengusahaan air tidak boleh mengganggu, mengesampingkan, apalagi meniadakan hak rakyat atas air karena bumi dan air dan kekayaan alam yang terkandung di dalamnya selain harus dikuasai oleh negara, juga peruntukannya adalah untuk sebesar-besarnya kemakmuran rakyat;

20 Soeroso, F. L. (2013). Pembangkangan Terhadap Putusan Mahkamah Konstitusi. Jurnal Yudisial. 6 (3), h. 235

${ }^{21}$ Lihat "Putusan Mahkamah Konstitusi Republik Indonesia Nomor 85/PUU-XI/2013". h. 138 \& 139

305 |S A S I Vo1.26 No.3, Juli - September 2020 
2) Negara harus memenuhi hak rakyat atas air. Sebagaimana dipertimbangkan diatas, akses terhadap air adalah salah satu hak asasi tersendiri maka Pasal 28I ayat (4) menentukan, Perlindungan, pemajuan, penegakan, dan pemenuhan hak asasi manusia adalah tanggung jawab negara, terutama pemerintah;

3) Mengingat kelestarian lingkungan hidup, sebab sebagai salah satu hak asasi manusia, Pasal 28H ayat (1) UUD 1945 menentukan, Setiap orang berhak hidup sejahtera lahir dan batin, bertempat tinggal, dan mendapat lingkungan hidup yang baik dan sehat serta berhak memperoleh pelayanan kesehatan;

4) Sebagai cabang produksi yang penting dan menguasai hajat hidup orang banyak yang harus dikuasai oleh negara [vide Pasal 33 ayat (2) UUD 1945] dan air yang menurut Pasal 33 ayat (3) UUD 1945 harus dikuasai oleh negara dan digunakan untuk sebesarbesar kemakmuran rakyat maka pengawasan dan pengendalian negara atas air sifatnya mutlak;

5) Kelanjutan hak menguasai oleh negara dan karena air merupakan sesuatu yang sangat menguasai hajat hidup orang banyak, maka prioritas utama yang diberikan pengusahaan atas air adalah Badan Usaha Milik Negara atau Badan Usaha Milik Daerah;

6) Apabila setelah semua pembatasan tersebut di atas sudah terpenuhi dan ternyata masih ada ketersediaan air, pemerintah masih dimungkinkan untuk memberikan izin kepada usaha swasta untuk melakukan pengusahaan atas air dengan syarat-syarat tertentu dan ketat".

Ke-enam prinsip tersebut, perlu diperhatikan oleh Pembentuk Undang-Undang dalam hal ini DPR dan Pemerintah. Agar produk hukum yang dihasilkan dalam bentuk UndangUndang Sumber Daya Air yang terbaru saat ini (UU No 17/2019), tidak lagi mengulangi fenome kegagalan pada tahun 2015 ketika UU SDA yang lama dibatalkan secara keseluruhan oleh Mahkamah Konstitusi. Begitu pun, ke-enam prinsip ini juga harus dimaknai secara komprehensif oleh Pemerintah agar tidak salah dalam membentuk peraturan pelaksanaannya. Melainkan, Pemerintah harus tetap berpedoman pada ke-enam prinsip penguasaan dan pembatasan pengeleloaan air yang diamanatkan oleh Putusan MK karena sejatinya menurut penulis di dalamnya sudah terkandung nilai-nilai Pancasila yang sebagaimana ditafsirkan oleh Mahkamah Konstitusi (the guardian of ideology).

\section{c. Peran BPIP dalam mengharmonisasi nilai-nilai Pancasila dengan Undang-Undang}

Fenome Putusan MK atas pengujian dan pembatalan secara keseluruhan ruh UU SDA (UU No 7 Tahun 2004) sebagimana telah diuraikan diatas sebetulnya telah menjadi mimpi buruk bagi DPR dan Pemerintah karena telah gagal dalam mengambil kebijakan. Fenomena itu, sekaligus menjadi pekerjaan rumah bagi DPR dan Pemerintah untuk segera melakukan peninjauan dan evaluasi terhadap seluruh produk hukum nasional baik itu, Undang-Undang maupun peraturan perundang-undangan lainnya apakah materi muatannya telah sesuai dengan nilai-nilai pancasila. Sebagai kepala negara sekaligus kepala pemerintahan Presiden mempunyai kewenangan untuk menyelenggarakan urusan pemerintahan umum (general competence) yaitu melakukan pembinaan dan pengamalan terhadap pancasila artinya bahwa Presiden bertanggung jawab mutlak atas pembinaan dan pengamalan pancasila. ${ }^{22}$

Maka, tanggung jawab Presiden itulah yang kemudian di delegasikan kepada Badan Pembinaan Ideologi Pancasila (BPIP). Eksistensi BPIP dalam sistem ketatanegaraan melalui

22 Aritonang, D. M. (2016). Pola Distribusi Urusan Pemerintahan Daerah Pasca Berlakunya UU No 23 Tahun 2014 tentang Pemerintahan Daerah. Jurnal Legislasi Indonesia. 13 (1), h. 48 
kebijakan Presiden dengan menetapkan Peraturan Presiden Nomor 7 Tahun 2018. Kebijakan Pemerintah ini merupakan respon Pemerintah atas ketidaksesuaian atau ketidaksinkronan peraturan perundang-undangan pada dewasa ini dengan nilai-nilai pancasila. Kehadiran BPIP dalam sistem presidensial bertujuan untuk membantu Presiden dalam merumuskan arah kebijakan pembinaan ideologi pancasila, melaksanakan koordinasi, sinkronisasi, dan pengendalian pembinaan ideologi pancasila secara menyeluruh dan berkelanjutan, dan melaksanakan penyusunan standardisasi pendidikan dan pelatihan serta memberikan rekomendasi berdasarkan hasil kajian terhadap kebijakan atau regulasi di Indonesia yang bertentangan/ tidak sesuai dengan nilai-nilai pancasila kepada lembaga tinggi negara, kementrian/ lembaga non kementrian, pemerintah daerah, organisasi sosial politik, dan komponen masyarakat lainnya. ${ }^{23}$

Jika, disandingkan peran BPIP dan Mahkamah Konstitusi dalam menjaga dan mengawasi kemurniaan nilai-nilai pancasila (the guardian of ideology). Maka, secara kelembagaan BPIP berperan sebagai lembaga negara yang menjalankan pengawasan yang bersifat prevensif artinya bahwa BPIP diposisikan sebagai lembaga controlling yang menilai dan mencegah terjadi ketidaksesuaian antara regulasi di Indonesia dengan nilai-nilai pancasila, serta mengharmonisasi semua regulasi dalam artian mengharmonisasi Rancangan Undang-Undang (RUU) sebelum menjadi Undang-undang agar tetap sesuai dengan koridornya yaitu nilai-nilai pancasila. Sementara itu, MK diposisikan sebagai lembaga yang menjalankan pengawasan yang bersifat represif artinya bahwa apabila ada regulasi dalam arti undang-undang yang bertentangan dengan nilai-nilai pancasila maka disitulah peran MK untuk membatalkan UU tersebut. Meskipun, eksistensi BPIP hanya bersandar pada payung hukumn setingkat Peraturan Presiden namun BPIP tetap mempunyai tugas dan kewenangan yang cukup besar dalam rangka mengharmonisasi regulasi dengan nilai-nilai pancasila. Maka sebetulnya, perlu dipikirkan kembali oleh pengambil kebijakan dalam hal ini Pemerintah dan DPR mengenai desain kelembagaan BPIP ini. Apakah masih harus dipertahankan kelembagaan BPIP dalam payung hukumnya yaitu Peraturan Presiden ataukah perlu diperkuatkan kelembagaannya dengan membentuk Undang-undang atau lebih ekstremnya memperkuat eksistensi kelembagaan BPIP dalam Konstitusi. Namun, menurut pandangan penulis apapun desain kelembagaan BPIP sejatinya harus tetap diperkuat eksistensinya baik itu dengan Undang-Undang maupun Konstitusi.

\section{PE N U T U P}

Berdasarkan pembahasan di atas, maka dapat disimpulkan bahwa penempatan Pancasila sebagai staatsfundamentalnorm pertama kali disampaikan oleh Notonagoro. Pancasila dilihat sebagai cita hukum (rechtsidee) merupakan bintang pemandu. Posisi ini mengharuskan pembentuk hukum positif adalah untuk mencapai ide-ide dalam Pancasila, serta dapat digunakan untuk menguji hukum positif, dengan ditempatkan Pancasila sebagai staatsfundamentalnorm maka pembentukan hukum, penerapan hukum, dan pelaksanaannya tidak dapat dilepaskan dari nilai-nilai Pancasila, dalam kerangka hukum positif Indonesia Pancasila ditempatkan sebagai sumber dari segala sumber hukum Negara. Apabila kita menganggap bahwa Pancasila merupakan sumber segala sumber hukum negara, maka setiap pembentukan hukum dalam arti undang-undang maupun Peraturan perundang-undangan lainnya harus mencerminkan nilai-nilai Pancasila. Apabila suatu produk hukum itu sesuai dengan nilai-nilai pancasila, maka itulah yang dinamakan Politik Hukum Ideal. Badan Pembinaan Ideologi Pancasila (BPIP) ditempatkan sebagai lembaga yang menjalankan fungsi pengawasan preventif artinya mencegah terjadinya ketidaksinkronan regulasi dengan

${ }^{23}$ Lihat Pasal 3 "Peraturan Presiden Nomor 7 Tahun 2018"

307 |S ASI Vol. 26 No.3, Juli-September 2020 
nilai-nilai pancasila. Pemerintah dan DPR, perlu meningkatkan kinerja pengharmonisasian, pembulatan, dan pemantapan segala produk hukum nasional dalam rangka menyeleraskan dengan nilai-nilai pancasila demi tercapainya pembaharuan produk hukum nasional yang ideal

\section{DAFTAR PUSTAKA}

\section{Jurnal}

[1] Aditya, Z. F. \& Winata, M. R. (2018). Rekonstruksi Hierarki Peraturan Perundang Undangan di Indonesia. Jurnal Negara Hukum. 9 (1): 88-89

[2] Arfa'i. (2015). Pembukaan UUD 1945 Sebagai Norma Hukum Dalam Etika Politik Guna Mencapai Tujuan Negara. Jurnal Ilmu Hukum. 6 (2): 91-92

[3] Amarini, I. (2017). Evaluasi Aktualisasi Pancasila Melalui Harmonisasi Hukum. Jurnal Kosmik Hukum. 17 (2): 80

[4] Aritonang, D. M. (2016). Pola Distribusi Urusan Pemerintahan Daerah Pasca Berlakunya UU No 23 Tahun 2014 tentang Pemerintahan Daerah. Jurnal Legislasi Indonesia. 13 (1): 48

[5] Brata, I. B \& Wartha, I. B. N. (2017). Lahirnya Pancasila sebagai Pemersatu Bangsa Indoensia. Jurnal Santiaji Pendidikan. 7 (1): 121

[6] Hardinanto, A. (2017). Autentitas Sumber Sejarah Pancasila Dalam Masa Persidangan Pertama Badan Untuk Menyelidiki Usaha-Usaha Persiapan Kemerdekaan Indonesia Tanggal 29 Mei - 1 Juni 1945. Jurnal veritas et justisia. 3 (1): 59

[7] Maulidi, M. A. (2017). Problematika Hukum Implementasi Putusan Final dan Mengikat Mahkamah Konstitusi Perspektif Negara Hukum. Ius Quia Iustum. 24 (4): 540

[8] Muladi. (2005). Menggali Kembali Pancasila sebagai Dasar Pembangunan Ilmu Hukum. Jurnal Hukum Progresif, Fakultas Hukum Universitas Diponegoro Semarang. 1 (1): 35

[9] Pusat Studi Konstitusi FH Andalas. (2010). Perkembangan Pengujian PerundangUndangan di Mahkamah Konstitusi. Jurnal Konstitusi. 7 (6) : h. 148

[10] Putera, A. (2018). Dualisme Pengujian Undang-Undang. Legislasi Indonesia. 15 (2): 72

[11] Rahayu, D. P. (2015). Aktualiasasi Pancasila Sebagai Landasan Politik Hukum Indonesia. Yustisia. 4 (1): 191

[12] Soeroso, F. L. (2013). Pembangkangan Terhadap Putusan Mahkamah Konstitusi. Jurnal Yudisial. 6. (3): 235

[13] Suwandi. (2018). Program Pembentukan Peraturan Daerah Perkemabangan dan Permasalahannya. Jurnal Legislasi Indonesia. 15 (3): 150

[14] Tardjono, H. (2016). Reorientasi Politik Hukum Pembentukan Undang-Undang di Indonesia. Jurnal Renaissance. 1 (2): 161

\section{Buku}

[15] Asshiddiqie, J. (2015). Penguatan Sistem Pemerintahan dan Peradilan, Jakarta: Sinar Grafika..

[16] Astomo, P. (2018). Ilmu Perundang-Undangan (Teori dan Praktik di Indonesia), Depok: Rajawali Pers.

[17] Hamidi, J. dkk. (2012). Teori Hukum Tata Negara "A Turning Point of The state" Jakarta: Salemba Humanika.

[18] Krisnayuda, B. (2017) Pancasila \& Undang-Undang "Relasi dan Transformasi 
Keduanya Dalam Sistem Ketatanegaraan Indonesia”, Jakarta: Kencana. [19] MD, Mahfud. (2012). Politik Hukum di Indonesia, Cet ke-V, Depok: Rajawali Pers 